\section{FINANCIAL PERFORMANCE COMPARISON (EMPIRIC STUDY ON CONVENTIONAL COMMERCIAL BANKS AND SHARIA COMMERCIAL BANKS 2012-2018)}

\author{
Akhmadi* \\ Ernis Chaerunisa \\ Shinta Zahra Chaerunisa \\ University of Sultan Ageng Tirtayasa, Serang, Indonesia
}

Financial

Performance

Comparison

(Empiric Study on

Conventional

Commercial Banks

and Sharia

Commercial Banks

2012-2018)

\begin{abstract}
This study aims to examine more the comparison of financial performance between Islamic Commercial Banks and Conventional Commercial Banks. The population in this study includes conventional banking companies and Islamic banking which are listed on the Indonesia Stock Exchange and supervised by the Financial Services Authority (OJK) for the period 2012-2018 as many as 114 companies. The observational data used were 56 data from 14 general and Islamic banks which were sampled in this study. The method of analysis used the normality test, the independent sample t-test, and the Mann-Whitney test. The results showed that there is no significant difference in the Capital Adequency Ratio between Conventional Commercial Banks and Islamic Commercial Banks, There is a significant difference in non-performing loans / financing (NPL / NPF) between Conventional Commercial Banks and Islamic Commercial Banks, there is a significant difference in return on assets (ROA) between Commercial Banks Conventional with Islamic Commercial Banks, there is a significant difference in operating expenses to operating revenue (BOPO) between Conventional Commercial Banks and Islamic Commercial Banks, there is a significant difference in loan / financing to deposit ratio between Conventional Commercial Banks and Shari'ah Commercial Banks.
\end{abstract}

Keywords: CAR, NPL / NPF, ROA, BOPO, LDR / FDR

*Corresponding author. Email address: akhmadi@untirta.ac.id

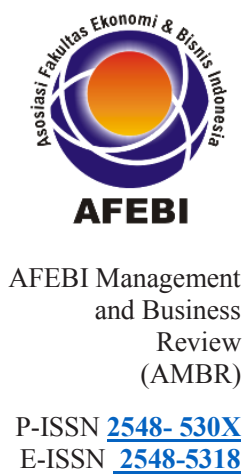


Every society is inseparable from economic activities and these activities certainly require transactions. Transactions are often carried out through a face-to-face process or transfer of funds through banks. The world of banking has currently implemented Law No. 10 of 1998, namely the dual banking system,which means that conventional banks in Indonesia are encouraged to open sharia business units or even fully convert them into sharia banks. The existence of two different banking systems in Indonesia triggers competition, this is because each bank must be more trustworthy and have its own advantages to gain loyalty from both customers and investors.

For investors who rely on fundamental information, the source of information used as the basis for decision making is financial reports, in addition to other non-fundamental information. Financial reports issued by companies are a form of communication from management to investors. From these financial reports, investors can assess the performance of management.

The difference in the financial performance conditions of Islamic Commercial Banks and Conventional Commercial Banks can be explained in the banking financial ratios in accordance with provisions No. 6/10 / PBI / 2004 dated 12 April 2004 which was later refined through regulation no 13/24 / DPNP dated 25 October 2011. The researcher presents financial performance ratios in the form of Capital Adequency Ratio (CAR), Non Performing Loan / Financing (NPL / NPF), Return Asset Ratio (ROA), Operating Expenses, Operating Income (BOPO), and Loan / Financing Depositor Ratio (LDR / FDR) in Islamic Commercial Banks and Conventional Commercial Banks based on National Banking Statistics published by the Financial Services Authority (OJK), as presented on the following chart:

Graph 1.

Graph 1.

Islamic

Commercial

Bank Ratio

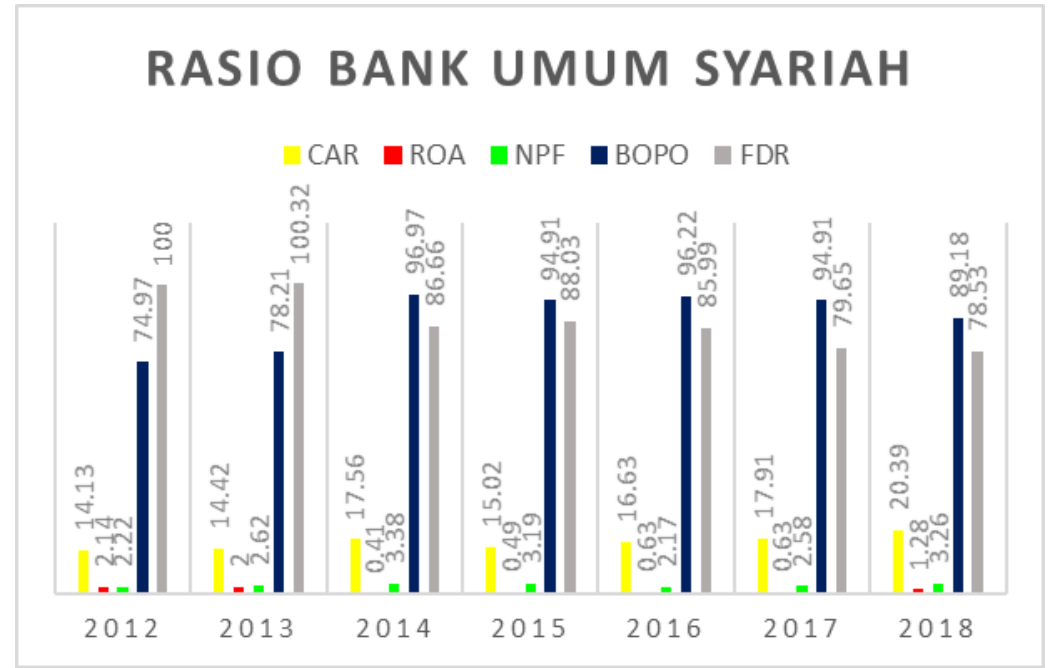

The performance of Syari'ah Commercial Banks during the 2012-2018 period was marked by a sharp decline in return on assets (ROA), from $2.14 \%$ in 2012 to only 0.41 in 2014 indicating a decrease in the optimization of company assets in generating profits. Even though in 2018 the ratio increased back to $1.28 \%$, but it was still below the 2012 ratio. BOPO also tended to increase from $74.97 \%$ in 2012 to $89.18 \%$ in 2018 , indicating a growth in operating costs that exceeded operating income. CAR tends to increase sharply from $14.13 \%$ in 2012 to 20.39 indicating strengthening company capital. The NPF also tended to increase from $2.22 \%$ to $3.26 \%$, indicating a decline in the quality of credit to borrowers. The tendency of FDR to decline quite significantly from $100 \%$ in 2012 to $78.53 \%$ indicates that it is less than optimal in channeling third party funds to debtors. In addition, the BOPO ratio from 2014 to 2018 was generally relatively stable at $74.97 \%-88.03 \%$, indicating that the company is able to control operating costs over its operating income. Based on the Bank Indonesia Regulation, BOPO is said to be quite healthy at a ratio of $85 \%-87 \%$. There is a downward trend in FDR from $100 \%$ in 2012 to $78.53 \%$ in 2018. Based on the Bank Indonesia Regulation, BOPO is said to be quite healthy at a ratio of $85 \%-87 \%$. There is a downward trend in FDR from 100\% in 2012 to $78.53 \%$ in 2018. Based on the Bank Indonesia Regulation, BOPO is said to be quite healthy at a ratio of $85 \%-87 \%$. There is a downward trend in FDR from $100 \%$ in 2012 to $78.53 \%$ in 2018 . 

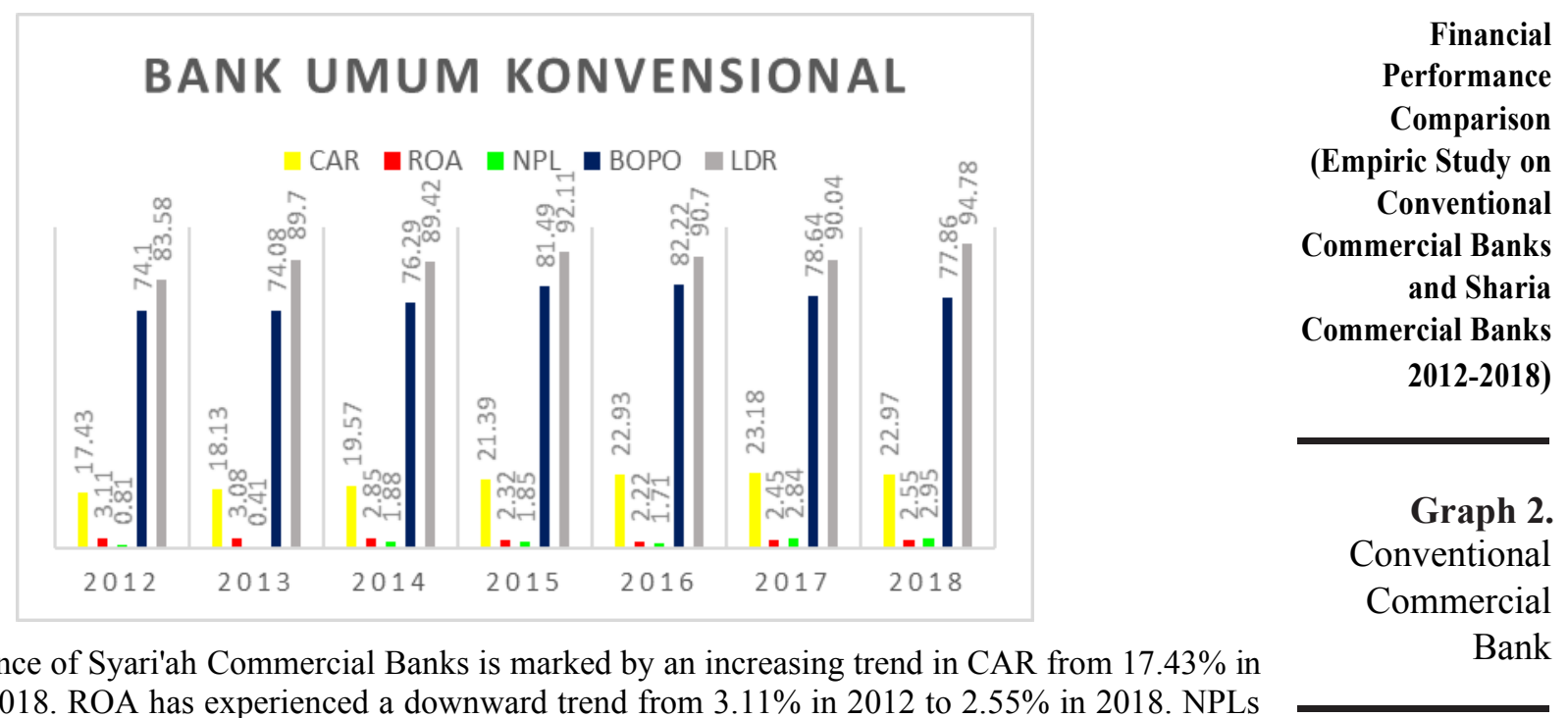

The performance of Syari'ah Commercial Banks is marked by an increasing trend in CAR from $17.43 \%$ in 2012 to $22.97 \%$ in 2018 . ROA has experienced a downward trend from $3.11 \%$ in 2012 to $2.55 \%$ in 2018 . NPLs fluctuated briefly from $0.81 \%$ in 2012 to $1.88 \%$ in 2014 , but after that the trend increased significantly so that it became 2.95 in 2018 . OEOI was relatively stable at a ratio of $74.10 \%-82.22 \%$. The LDR trend showed an increase from $83.58 \%$ in 2012 to $94.78 \%$.It is clear that the CAR and ROA of Conventional Commercial Banks are higher than Syari'ah Commercial Banks, indicating that Conventional Commercial Banks have better capital adequacy ratios and operational efficiency. The NPF of Syari'ah Commercial Banks is higher than the NPL of Conventional Commercial Banks, indicating that the quality of financing for Syari'ah Commercial Banks is worse.The FDR of Syari'ah Commercial Banks is higher than the LDR Conventional Commercial Bank, indicating channeling credit / financingShari'ah Commercial Banks are more aggressive. Meanwhile, there is no significant difference for BOPO.

Differences in performance are also described in previous studies. ResearchThayib et.al (2017) who prove that the CAR ratio in Conventional Commercial Banks is higher than the CAR for Islamic Commercial Banks. It's differentToin (2014) provides proves empirically that the CAR of Conventional Commercial Banks and Islamic Commercial Banks is not a significant difference. ResearchSetyaningsih and Utami (2013) prove that the NPL / NPF of Islamic Commercial Banksbetter than Conventional Commercial Banks. In contrast toToin (2014) which proves that there is none the difference in NPL / NPF between Islamic Commercial Banks and Conventional Commercial Banks. Arinta's research (2016) proves that the ROA of Conventional Commercial Banks is superior to Islamic Commercial Banks. Different fromSolikah et.al (2017) which proves that there is no significant difference between ROA of Conventional Commercial Banks and Islamic Commercial Banks. Suyono's research (2017) proves thatthere is no significant difference between the BOPO of Islamic Commercial Banks and the BOPO of Conventional Commercial Banks. Different fromWijayanti et.al (2017) which proves that BOPO of Conventional Commercial Banks is better than Islamic Commercial Banks. Rosiana and Triaryati's (2016) research proves thatThe LDR / FDR of Islamic Commercial Banks is higher than Conventional Commercial Banks. In contrast to Fahmi, et.al (2018) which proved that there was no significant difference in LDR / FDR between Islamic Commercial Banks and Conventional Commercial Banks.

Based on the business phenomenon and the inconsistency of the results of previous research, the researchers reviewed the financial performance of Islamic Commercial Banks with Conventional Commercial Banks. Although similar studies have been conducted, they are still in limited numbers. Disanmping that previous studies still present mixed results or are still ambiguous, thus indicating that the results are not yet well established. Based on these reasons, the researcher intends to examine more deeply the research with this topic. It is hoped that a clear comparison of financial performance can be obtained between Islamic Commercial Banks and Conventional Commercial Banks.

\section{HYPOTHESIS DEVELOPMENT}

Comparison of Capital Adequacy Ratio between Conventional Commercial Banks and Islamic Commercial Banks

Agency theory is closely related to the performance of conventional commercial banks and Islamic commercial banks. Shareholders as principals must control to determine the bank's financial performance during a certain period. The information submitted by the company will be considered by customers and investors (Budiartini, et.al, 2017). The results of the research are in accordance with the explanation presented bySapariyah et.al (2017), Rahayu et.al (2017), Thayib et.al (2017), Samad and Anan (2017), and Tabash et.al (2017), that there is a difference in CAR between Conventional Commercial Banks and Banks Sharia General.

HI: There are significant differences in CARs in Conventional Commercial Banks and Sharia Commercial Banks.. 
Agency theory is closely related to the performance of conventional commercial banks and Islamic commercial banks. Shareholders as Principals must know the bank's financial performance in the company in terms of agents. This is because the information submitted by the company will be considered by customers and investors (Budiartini, et.al, 2017). Research results that are in accordance with the researcher's hypothesis include research byWijayanti et.al (2017), Samad and Anan (2017), Setyabudi et.al (2017), Fahmi et.al (2018), Ramlan et.al (2018), that there is a difference in NPL / NPF between Conventional Commercial Banks and Sharia Commercial Bank.

H2: There is a significant difference in NPL / NPF in Conventional Commercial Banks and Sharia Commercial Banks

Comparison of Return On Asset Ratio between Conventional Commercial Banks and Islamic Commercial Banks Agency theory is closely related to the performance of conventional commercial banks and Islamic commercial banks. Shareholders as Principals must know the bank's financial performance in the company in terms of agents. This is because the information submitted by the company will be considered by customers and investors (Budiartini, et.al, 2017). Research results that are in accordance with the researcher's hypothesis include research byIbrahim (2016), Samad and Anan (2017), Wijayanti (2017), Sapariyah et.al (2017) and Khan (2018), that there is a difference in ROA between Conventional Commercial Banks and Islamic Commercial Banks. H3: There is a significant difference in ROA in Conventional Commercial Banks and Islamic Commercial Banks.

Comparison of Operating Expenses to Operating Avanue between Conventional Commercial Banks and Islamic Commercial Banks

Agency theory is closely related to the performance of conventional commercial banks and Islamic commercial banks. Shareholders as Principals must know the bank's financial performance in the company in terms of agents. This is because the information submitted by the company will be considered by customers and investors (Budiartini, et.al, 2017). Research results that are in accordance with the researcher's hypothesis include research bySolikah et.al (2016), Wijayanti (2017), Wahyuni and Efriza (2017), Tabash (2017) and Khan (2017), that there is a difference in BOPO between Conventional Commercial Banks and Islamic Commercial Banks. H4: There is a significant difference between BOPO in Conventional Commercial Banks and Islamic Commercial Banks.

Comparison of Loan / Financing to Deposit Ratio between Conventional Commercial Banks and Islamic Commercial Banks

Agency theory is closely related to the performance of conventional commercial banks and Islamic commercial banks. Shareholders as Principals must know the bank's financial performance in the company in terms of agents. This is because the information submitted by the company will be considered by customers and investors (Budiartini, et.al, 2017). The results of the research are in accordance with the researcher's hypothesis among other research byThayib et.al (2017), Sapariyah et.al (2017), Hardianti and Saifi (2018), Khan (2018) and Dodoev (2018), that there is a difference in LDR / FDR between Conventional Commercial Banks and Islamic Commercial Banks.

H5: There is a significant difference in LDR / FDR in Conventional Commercial Banks and Islamic Commercial Banks

\section{METHODOLOGY}

\section{Types of research}

This research is a comparative study (Comparative Study), in this study it is used to compare financial performance between conventional banks and Islamic banks.

\section{Population and Sample.}

The population in this study includes conventional banking companies and Islamic banking which are listed on the Indonesia Stock Exchange and supervised by the Financial Services Authority (OJK) for the period 20122018 as many as 114 companies. While the sample was determined as many as 14 companies that were determined by prurposive sampling technique with criteria; Consiten listing on the Indonesia Stock Exchange during the period 2012-2018, and witnessing complete financial data in accordance with the variables observed in the study. The observation data used were 56 data, derived from 14 samples of conventional commercial banks and Islamic commercial banks, multiplied by 4 quarters in a year, then clicked by 7 years of the observation period. Observation data is intended to be collected from the Indonesian Directory Exchane (IDX) of the Indonesia Stock Exchang. 
The variable examined in this research is CAR, which is proxied by the comparison of Core Capital and Supplementary Capital with Risk Weighted Assets. NPL / NPF is proxied by the ratio of Total Non Performing Loans to Total Loans. ROA is proxied by the ratio of Net Profit Before Tax to Total Assets. BOPO is proxied by a comparison of Operating Costs and Operating Income. LDR / FDR is proxied by the ratio of Third Party Funds to Total Loans, (Rivai, et.al 2013).

\section{Statistical Data Analysis}

(Empiric Study on

Conventional

Commercial Banks

and Sharia

Descriptive statistics

Commercial Banks

2012-2018)

In order to know the distribution of data, descriptive statistics are used using descriptive parameters to describe the data related to the minimum value, maximum value, average value and standard deviation value. Meanwhile, to test the difference in performance used inferential statistics with different test parameters using the independent sample t-test to test the mean difference between the two independent groups on the interval / ratio scale. Mann-Whitney test, to determine the difference between 2 independent groups on a ratio scale, (Wijayanti et.al 2017).

\section{Inferential Statistics}

Normality test

Using the Kolmogrov-Smirnov (KS) test parameters. The distributed data is said to be normal if the significance value is $\geq 0.05$ then Ho is accepted and the data is said to be abnormal if it has a significant value $\leq 0.05$ then Ho is rejected,(Ghozali, 2016).

\section{Hypothesis Test:}

Test Independent Sample T-Test

To find out whether there is a difference in the mean between the two independent groups on the interval / ratio scale, it is used independent sample t-test. If the significance value or Sig. (2-tailed) $<0.05$, $\mathrm{t}$ count $>\mathrm{t}$ table then $\mathrm{Ho}$ is rejected and $\mathrm{Ha}$ is accepted. Meanwhile, if the significance value or Sig. (2-tailed) $>0.05$, t count $<\mathrm{t}$ table then $\mathrm{H} 0$ is accepted and $\mathrm{Ha}$ is rejected (Wijayanti et al., 2017). In this regard, the test was carried out to determine the difference in performance between conventional commercial banks and syari'ah public banks.

Mann-Whitney test

The Mann Whitney test is a non-parametric test that is used to determine the difference between the 2 independent groups on the ratio scale. This test is used to test the financial performance of conventional banks and Islamic banks if the data is not normally distributed.If the value of significance or Asymp. Sig. (2-tailed) $<0.05$, then Ho is rejected. Meanwhile, if the significance value or Asymp. Sig. (2-tailed) $>0.05$, then Ho is accepted (Wijayanti et al, 2017).

Table 1

Descriptive

\section{RESULTS}

Descriptive Statistics

\begin{tabular}{|c|c|c|c|c|c|c|c|}
\hline \multicolumn{2}{|c|}{ commercial banks } & $\mathrm{N}$ & Minimum & Maximum & Mean & $\begin{array}{c}\text { Std. } \\
\text { Deviation }\end{array}$ & $\begin{array}{c}\text { Std. Mean } \\
\text { Error }\end{array}$ \\
\hline $\begin{array}{c}\text { Capital } \\
\text { Adequency } \\
\text { ratio }\end{array}$ & Conventional & 196 & 10.52 & 26.21 & 18.0833 & 3,03720 &, 21694 \\
\cline { 2 - 8 } & Sharia & 196 & 10.74 & 44.50 & 19,1380 & 6.77265 &, 48376 \\
\hline
\end{tabular}

Statistics Capital

Adequency Ratio

(CAR)

Conventional

Commercial Banks and Islamic

Commercial Banks 2012-2018

Source: SPSS 20 output (processed data) 
The higher the CAR value, the better the Bank's management of capital, especially in facing possible risk of loss. Based on these conditions, Islamic Commercial Banks are proven to be superior to Conventional Commercial Banks, namely $19.138 \%>18.083 \%$. This means that Islamic Commercial Banks have better capital quality compared to Conventional Commercial Banks.

Table 2

Non-Performing

Loan / Financing

(NPL / NPF)

Descriptive Statistics Conventional

Commercial Banks and Islamic

Commercial Banks 2012-2018

\begin{tabular}{|c|c|c|c|c|c|c|c|}
\hline \multicolumn{2}{|c|}{ commercial banks } & N & Minimum & Maximum & Mean & $\begin{array}{c}\text { Std. } \\
\text { Deviation }\end{array}$ & $\begin{array}{c}\text { Std. } \\
\text { Mean } \\
\text { Error }\end{array}$ \\
\hline $\begin{array}{c}\text { Non Performing } \\
\text { Loan / Financing }\end{array}$ & Conventional & 196 & 0.00 & 6.37 & 1,2924 & 1.10656 & $\begin{array}{c}0 \\
0\end{array}$ \\
\cline { 2 - 8 } & Sharia & 196 & -0.04 & 6.44 & 2,2628 & 1,50088 & $\begin{array}{c}1 \\
10721\end{array}$ \\
\hline
\end{tabular}

Source: SPSS 20 output (processed data)

The smaller the NPL / NPF value indicates the better the Bank is in asset management, especially in analyzing the level of non-performing loans. Judging from the magnitude of the ratio calculation, Islamic Commercial Banks are superior to Conventional Commercial Banks, namely $1.2924 \%<2.2628 \%$. This means

Table 3

Descriptive Statistics Return on Assets (ROA)

Conventional Commercial Banks and Islamic Commercial Banks 2012-2018 Banks.

\begin{tabular}{|c|c|c|c|c|c|c|c|}
\hline \multicolumn{2}{|c|}{ commercial banks } & \multirow{2}{*}{\begin{tabular}{|c|}
$\mathrm{N}$ \\
196
\end{tabular}} & \multirow{2}{*}{$\begin{array}{c}\text { Minimum } \\
0.09\end{array}$} & \multirow{2}{*}{$\begin{array}{c}\text { Maximum } \\
5.15\end{array}$} & \multirow{2}{*}{$\begin{array}{l}\text { Mean } \\
2.6245\end{array}$} & \multirow{2}{*}{$\begin{array}{c}\begin{array}{c}\text { Std. } \\
\text { Deviation }\end{array} \\
1,18760\end{array}$} & \multirow{2}{*}{$\begin{array}{c}\text { Std. } \\
\text { Mean } \\
\text { Error } \\
, \\
08483\end{array}$} \\
\hline $\begin{array}{c}\text { Non } \\
\text { Performing }\end{array}$ & Conventional & & & & & & \\
\hline $\begin{array}{c}\text { Loan } / \\
\text { Financing }\end{array}$ & Sharia & 196 & -8.18 & 4.86 & 1,0948 & 1,54856 & 11061 \\
\hline
\end{tabular}

Source: SPSS 20 output (processed data)

The greater the ROA value indicates that the Bank is better at managing assets in increasing revenue. Judging from the calculation of the ROA ratio, Conventional Commercial Banks are superior to Islamic Commercial Banks, namely 2.2645\%> 1.0948\%. This means that Conventional Commercial Banks are better at

Table 4 managing overall profits.

Descriptive

Statistics

Operating

Expenses To

Operating Avanue

(BOPO)

Conventional

Commercial Banks

and Islamic

\begin{tabular}{|c|c|c|c|c|c|c|c|}
\hline \multicolumn{2}{|c|}{ commercial banks } & N & Minimum & Maximum & Mean & $\begin{array}{c}\text { Std. } \\
\text { Deviation }\end{array}$ & $\begin{array}{c}\text { Std. } \\
\text { Mean } \\
\text { Error }\end{array}$ \\
\hline $\begin{array}{c}\text { Operating } \\
\text { Expenses to } \\
\text { Operating Avanue }\end{array}$ & Conventional & 196 & 58.24 & 100.24 & 75,607 & 10,5817 & \begin{tabular}{c}
77513 \\
\cline { 2 - 8 }
\end{tabular} \\
\hline
\end{tabular}

Commercial Banks Source: SPSS 20 output (processed data)

2012-2018

The smaller the BOPO value indicates the better the Bank is in managing its operations in increasing revenue. Judging from the magnitude of the calculation of the BOPO ratio, Conventional Commercial Banks are superior to Islamic Commercial Banks, namely 75.607\% $<92.357 \%$. This means that Conventional Commercial Banks are better at taking advantage of their operational management. 


\begin{tabular}{|c|c|c|c|c|c|c|c|}
\hline \multicolumn{2}{|c|}{ commercial banks } & N & Minimum & Maximum & Mean & $\begin{array}{c}\text { Std. } \\
\text { Deviation }\end{array}$ & $\begin{array}{c}\text { Std. } \\
\text { Mean } \\
\text { Error }\end{array}$ \\
\hline $\begin{array}{c}\text { Loan / Financing } \\
\text { Deposit Ratio }\end{array}$ & Conventional & 196 & 52.39 & 96.74 & 78,807 & 10,0322 &, 71659 \\
\cline { 2 - 8 } & Sharia & 196 & 46.08 & 110.13 & 92,357 & 8,57782 &, 61270 \\
\hline
\end{tabular}

Source: SPSS 20 output (processed data)

The smaller the LDR value indicates the Bank is getting better at managing its operations in increasing revenue, but at a certain point it should not be smaller than the specified ratio. Judging from the magnitude of the calculation of the LDR ratio, Conventional Commercial Banks are superior to Islamic Commercial Banks, namely $75.607 \%<92.357 \%$. The meaningConventional Commercial Banks have a better level of liquidation, so that Conventional Commercial Banks have a better ability to meet credit requests submitted by customers.

Inferential Statistics

Normality test

\begin{tabular}{|l|l|r|r|r|r|r|r|}
\hline & \multirow{2}{*}{$\begin{array}{l}\text { lommercial } \\
\text { banks }\end{array}$} & \multicolumn{2}{|c|}{ Kolmogorov-Smirnova } & \multicolumn{3}{|c|}{ Shapiro-Wilk } \\
\cline { 2 - 7 } & Statistics & \multicolumn{1}{c|}{ df } & \multicolumn{1}{c|}{ Sig. } & Statistics & \multicolumn{1}{c|}{ df } & Sig. \\
\hline $\begin{array}{l}\text { Capital } \\
\begin{array}{l}\text { Adequency } \\
\text { ratio }\end{array}\end{array}$ &, 077 & 196 &, 007 &, 980 & 196 &, 006 \\
& Sharia &, 160 & 196 &, 000 &, 861 & 196 &, 000 \\
\hline
\end{tabular}

a. Lilliefors Significance Correction

Source: SPSS 20 output (processed data)

The Kolmogrov-Smirnov test shows asymp. The Sig of Conventional Commercial Banks has a value of $0.007<0.05$, and Islamic Commercial Banks have a value of $0.000<0.05$, this indicates that the data is not normally distributed. Solutions to make data normally distributed include transforming it into Ln form, removing data that deviates / outliers and leaving it alone and then using other alternative tests, one of which is testing data with Mann Whitney (Suliyanto, 2011: 78:79). The transformation of the observational data has been attempted to use natural logs (Ln), and discarding some of the oulier data, the normality test results still produce a sig value of Kolmogrov Smirnov $<0.05$. These results indicate that the dataCapital Adequency Ratio (CAR)not normally distributed.

\begin{tabular}{|l|l|r|r|r|r|r|r|}
\hline & \multirow{2}{*}{$\begin{array}{l}\text { commercial } \\
\text { banks }\end{array}$} & \multicolumn{3}{|c|}{ Kolmogorov-Smirnova } & \multicolumn{3}{|c|}{ Shapiro-Wilk } \\
\cline { 2 - 7 } & Statistics & \multicolumn{1}{c|}{ Df } & Sig. & Statistics & \multicolumn{1}{c|}{ Df } & Sig. \\
\hline Non Performing & Conventional &, 147 & 196 &, 000 &, 860 & 196 &, 000 \\
Loan / Financing & Sharia &, 090 & 196 &, 001 &, 951 & 196 &, 000 \\
\hline
\end{tabular}

a. Lilliefors Significance Correction

Source: SPSS 20 output (processed data)

Kolmogrov-Smirnov test looks asymp. The Sig of Conventional Commercial Banks has a value of 0.000 $<0.05$, and Islamic Commercial Banks have a value of $0.001<0.05$, this indicates that the data is abnormally distributed. There is a solution to making data normally distributed, among others, by transforming it into an Ln form, issuing data that is not normally distributed. deviating / Outlier and being left alone then using other test alternatives, one of which is testing the data with Mann Whitney (Suliyanto, 2011: 78:79). The observation data has been transformed into a natural $\log (\mathrm{Ln})$ form, and discarding some of the oulier data, the normality test results still produce the sig value of Kolmogrov Smirnov $<0.05$. These results indicate that the dataNon Performing Loan / Financing (NPF / NPL) not normally distributed.
Financial

Performance

Comparison

(Empiric Study on

Conventional

Commercial Banks

and Sharia

Commercial Banks

2012-2018)

Table 5

Loan / Financing

Deposit

Ratio (LDR

/ FDR)

Descriptive

Statistics

Conventional

Commercial Banks

and Islamic

Commercial Banks

2012-2018

Table 6

Kolmogorov-

Smirnov

Normality

Test Capital

Adequency

Ratio

(CAR)

Table 7

Kolmogorov-

Smirnov

Normality

Test for

Non

Performing

Loan /

Financing

(NPF /

NPL) 


\begin{tabular}{|l|l|r|r|r|r|r|r|}
\hline & commercial & \multicolumn{3}{|c|}{ Kolmogorov-Smirnova } & \multicolumn{3}{|c|}{ Shapiro-Wilk } \\
\cline { 3 - 8 } & banks & Statistics & \multicolumn{1}{c|}{ Df } & Sig. & Statistics & \multicolumn{1}{c|}{ df } & \multicolumn{1}{c|}{ Sig. } \\
\hline Return On & Conventional &, 099 & 196 &, 000 &, 974 & 196 &, 001 \\
Assets & Sharia &, 183 & 196 &, 000 &, 802 & 196 &, 000 \\
\hline
\end{tabular}

Table 8

a. Lilliefors Significance Correction

Kolmogorov-

Smirnov Normality

Test Return on

Asset (ROA)

Source: SPSS 20 output (processed data)

Kolmogrov-Smirnov test looks asymp. The Sig of Conventional Commercial Banks has a value of 0.000 $<0.05$, and Islamic Commercial Banks have a value of $0.000<0.05$, this indicates that the data is abnormally distributed.There is a solution to making data normally distributed, among others, by transforming it into an LN form, issuing data that is not normally distributed. deviating / Outlier and being left alone then using other test alternatives, one of which is testing the data with Mann Whitney (Suliyanto, 2011: 78:79). The observation data has been transformed into a natural $\log (\mathrm{Ln})$ form, and discarding some of the oulier data, the normality test results still produce the sig value of Kolmogrov Smirnov $<0.05$. These results indicate that the dataReturn on Asset (ROA) not normally distributed.

Table 9

KolmogorovSmirnov Normality Test

Operating Expenses To Operating Avanue (BOPO)

\begin{tabular}{|l|l|r|r|r|r|r|r|}
\hline & commercial banks & \multicolumn{2}{|c|}{ Kolmogorov-Smirnova } & \multicolumn{3}{|c|}{ Shapiro-Wilk } \\
\cline { 3 - 7 } & & Statistics & df & Sig. & Statistics & \multicolumn{1}{c|}{ df } & Sig. \\
\hline Operating Expenses to & Conventional &, 126 & 196 &, 000 &, 945 & 196 &, 000 \\
Operating Avanue & Sharia &, 213 & 196 &, 000 &, 701 & 196 &, 000 \\
\hline
\end{tabular}

a. Lilliefors Significance Correction

Source: SPSS 20 output (processed data)

Kolmogrov-Smirnov test looks asymp. The Sig of Conventional Commercial Banks has a value of 0.000 $<0.05$, and Islamic Commercial Banks have a value of $0.000<0.05$, this indicates that the data is not normally distributed. Solutions to make data normally distributed include transforming it into an LN form, removing distorted data / outliers and leaving it alone then using other testing alternatives, one of which is data testing with Mann Whitney (Suliyanto, 2011: 78:79). The observation data has been transformed into a natural $\log (\mathrm{Ln})$ form, still resulting in the sig value of Kolmogrov Smirnov $<0.05$. However, after removing some of the oulier data, the normality test results still produced the sig value of Kolmogrov Smirnov $=0.359>0.05$. These results indicate that the dataOperating Expenses to Operating Revenue (BOPO) normally distributed.

Table 10

Kolmogorov-

Smirnov Normality

Test for Outlier Data

Operating Expenses

to Operating Avanue (BOPO)

\begin{tabular}{|l|l|r|r|r|r|r|r|}
\hline \multirow{2}{*}{} & commercial & \multicolumn{3}{|c|}{ Kolmogorov-Smirnova } & \multicolumn{3}{|c|}{ Shapiro-Wilk } \\
\cline { 2 - 8 } & banks & Statistics & \multicolumn{1}{c|}{ df } & \multicolumn{1}{c|}{ Sig. } & Statistics & \multicolumn{1}{c|}{ df } & \multicolumn{1}{c|}{ Sig. } \\
\hline Operating Expenses to Conventional &, 126 & 196 &, 000 &, 945 & 196 &, 000 \\
Operating Avanue & Sharia &, 046 & 174 &, $200 *$ &, 991 & 174 &, 359 \\
\hline
\end{tabular}

a. Lilliefors Significance Correction

Source: SPSS 20 output (processed data)

Table 11

Kolmogorov-

Smirnov Normality

Test

Loan / Financing

Deposit Ratio (LDR

FDR)

\begin{tabular}{|l|l|r|r|r|r|r|r|}
\hline & commercial banks & \multicolumn{3}{|c|}{ Kolmogorov-Smirnova } & \multicolumn{3}{|c|}{ Shapiro-Wilk } \\
\cline { 3 - 8 } & & Statistics & \multicolumn{1}{c|}{ df } & \multicolumn{1}{c|}{ Sig. } & Statistics & \multicolumn{1}{c|}{ df } & Sig. \\
\hline Loan / Financing & Conventional &, 078 & 196 &, 005 &, 962 & 196 &, 000 \\
Deposit Ratio & Sharia &, 059 & 196 &, 094 &, 968 & 196 &, 000 \\
\hline
\end{tabular}

a. Lilliefors Significance Correction

Source: SPSS 20 output (processed data) 
Kolmogrov-Smirnov test looks asymp. Sig Conventional Commercial Banks have a value of $0.005<0.05$, and Islamic Commercial Banks have a value of 0.094>0.05. Even though Islamic Commercial Banks are normally distributed, Conventional Commercial Banks are not normally distributed. So the solution to making data is normally distributed, among others, is transformed into an Ln form, removing deviating data / outliers and leaving it alone then using other testing alternatives, one of which is testing the data with Mann Whitney (Suliyanto, 2011: 78:79). The observation data has been transformed into a natural $\log (\mathrm{Ln})$ form, still resulting in the sig value of Kolmogrov Smirnov $<0.05$. However, after removing some of the oulier data, the normality test results still produce the sig value of Kolmogrov Smirnov $=0.361>0$,Loan $/$ Financing Deposit Ratio $($ LDR $/$ FDR) normally distributed

\begin{tabular}{|l|l|r|r|r|r|r|r|}
\hline & \multirow{2}{*}{ commercial banks } & \multicolumn{2}{|c|}{ Kolmogorov-Smirnova } & \multicolumn{3}{|c|}{ Shapiro-Wilk } \\
\cline { 3 - 7 } & & Statistics & df & Sig. & Statistics & \multicolumn{1}{c|}{ Df } & Sig. \\
\hline Loan / Financing & Conventional &, 078 & 196 &, 005 &, 962 & 196 &, 000 \\
Deposit Ratio & Sharia &, 056 & 195 &, $200 *$ &, 992 & 195 &, 361 \\
\hline
\end{tabular}

a. Lilliefors Significance Correction

Source: SPSS 20 output (processed data)

\section{Mann-Whitney Difference Test}

The difference test in this study uses the Mann-Whitney Difference Test, because most of the observation data are not normally distributed, (Wijayanti et.al, 2017). Following are the test results for each variable.

Statistics Test a

\begin{tabular}{|l|r|}
\hline & \multicolumn{1}{|c|}{ Capital Adequency ratio } \\
\hline Mann-Whitney U & 17813,500 \\
Wilcoxon W. & 37119,500 \\
Z & $-1,243$ \\
Asymp. Sig. (2-tailed) &, 214 \\
\hline
\end{tabular}

a. Grouping Variable: Commercial Banks

Source: SPSS Output (Processed data)

The results of the asymp sig value of the Capital Adequency Ratio based on the Mann-Whitney test were $0.214>0.05$ with a $Z$ value of -1.243 and the Mann-Whitney $U$ of 17813.5. The difference is significant if Asymp. The Mann-Whitney Sig (2-tailed) shows a number $<0.05$. Whereas there is no significant difference if the MannWhitney Asymp.Sig (2-tailed) shows a number $>0.05$ (Wiayanti et.al, 2017). Based on these results, there is no significant difference in the Capital Adequency Ratio between Conventional Commercial Banks and Islamic Commercial Banks. In conclusion H01 Accepted.

\begin{tabular}{|l|r|}
\hline & Non Performing Loan / Financing \\
\hline Mann-Whitney U & 12078,500 \\
Wilcoxon W. & 31384,500 \\
Z & $-6,356$ \\
Asymp. Sig. (2-tailed) &, 000 \\
\hline
\end{tabular}

a. Grouping Variable: Commercial Banks
Financial

Performance

Comparison

(Empiric Study on

Conventional

Commercial Banks

and Sharia

Commercial Banks

2012-2018)

Table 12

KolmogorovSmirnov Normality Test for Outlier Data Loan / Financing

Deposit Ratio

(LDR / FDR)

Table 13

The Mann-Whitney

Capital

Adequency

Difference Test

Ratio (CAR)

Table 14

Mann-Whitney

Normality Test

Non Performing

Loan /

Financing (NPL

/NPF) 
The result of the asymp sig value of Non Performing Loan / Financing based on the Mann-Whitney test is $0.000<0.05$ with a $Z$ value of -6.356 and a Mann-Whitney $U$ of 12078.5 . Based on these results, there is a significant difference in Non Performing Loans / Financing between Conventional Commercial Banks and Islamic Commercial Banks. In accordance with (Wiayanti et.al, 2017), that the difference is significant if Asymp. The Mann-Whitney Sig (2-tailed) shows a number $<0.05$. Whereas there is no significant difference if the MannWhitney Asymp.Sig (2-tailed) shows a number $>0.05$. In conclusion H02 Rejected.

\section{Table 15}

Mann-Whitney Normality Test Return On Asset Ratio (ROA)

\section{Table 16}

Mann-Whitney Normality Test Operating Expenses To Operating Avannue (BOPO)

\section{Table 17}

Mann-Whitney

Normality Test

Loan / Financing to

Deposit Ratio (LDR (FDR)

\begin{tabular}{|l|r|}
\hline & \multicolumn{1}{|c|}{ Return On Asset Ratio } \\
\hline Mann-Whitney U & 7471,500 \\
Wilcoxon W. & 26777,500 \\
Z & $-10,464$ \\
Asymp. Sig. (2-tailed) &, 000 \\
\hline
\end{tabular}

a. Grouping Variable: Commercial Banks

The result of the asymp sig value of Return On Asset Ratio based on the Mann-Whitney test is 0.000 $<0.05$ with a $Z$ value of -10.464 and a Mann-Whitney $U$ of 7471.5 . Based on these results, there is a significant difference in the Return On Asset Ratio between Conventional Commercial Banks and Islamic Commercial Banks. In accordance (Wiayanti et.al, 2017), that the difference is significant if Asymp. The Mann-Whitney Sig (2-tailed) shows a number $<0.05$. Whereas there is no significant difference if the Mann-Whitney Asymp.Sig (2-tailed) shows a number $>0.05$. Based on these results, the conclusion is H03 Rejected.

\begin{tabular}{|l|r|}
\hline & Operating Expenses to Operating Avanue \\
\hline Mann-Whitney U & 5133,000 \\
Wilcoxon W. & 24439,000 \\
Z & $-12,548$ \\
Asymp. Sig. (2-tailed) &, 000 \\
\hline
\end{tabular}

a. Grouping Variable: Commercial Banks

Source: SPSS Output (Processed data)

The results of the asymp sig value of Operating Expenses to Operating Avanue based on the MannWhitney test are $0.000<0.05$ with a $Z$ value of -12.548 and a Mann-Whitney $U$ of 5133.5. Referring to (Wiayanti et.al, 2017), that the difference is significant if Asymp. The Mann-Whitney Sig (2-tailed) shows a number $<0.05$. Meanwhile, there is no significant difference if the Mann-Whitney Asymp.Sig (2-tailed) shows a number $>0.05$. Based on these results, there is a significant difference in Operating Expenses to Operating Avanue between Conventional Commercial Banks and Islamic Commercial Banks. In conclusion H04 Rejected.

\begin{tabular}{|l|r|}
\hline & Loan / Financing Deposit Ratio \\
\hline Mann-Whitney U & 8063,000 \\
Wilcoxon W. & 27369,000 \\
Z & $-9,936$ \\
Asymp. Sig. (2-tailed) &, 000 \\
\hline
\end{tabular}

a. Grouping Variable: Commercial Banks

Source: SPSS Output (Processed data) 
The result of the asymp sig value of the Loan / Financing to Deposit Ratio based on the Mann-Whitney test is $0.000<0.05$ with a $Z$ value of -12.548 and a Mann-Whitney $U$ of 5133.5. Referring to (Wiayanti et.al, 2017), that the difference is significant if Asymp. The Mann-Whitney Sig (2-tailed) shows a number $<0.05$. Whereas there is no significant difference if the Mann-Whitney Asymp.Sig (2-tailed) shows a number $>0.05$. Based on these results, there is a significant difference in the Loan / Financing to Deposit Ratio between Conventional Commercial Banks and Islamic Commercial Banks. In conclusion H05 Rejected.

\section{DISCUSSION}

Comparison of Capital Adequacy Ratio between Conventional Commercial Banks and Islamic Commercial Banks The test results which show that there is no significant difference in the Capital Adequency Ratio between Conventional Commercial Banks and Islamic Commercial Banks, are not in accordance with the expectations of the researcher. The results are also irrelevant Sapariyah et.al (2017), Rahayu et.al (2017), Thayib et.al (2017), Samad and Anan (2017) which prove that there are significant differences. However, the results are in accordance with Arinta (2016), Fahmi et.al (2018), and Hardianti and Saifi (2018) which prove that there is no significant difference between the capital adequacy ratio of Islamic Commercial Banks and Conventional Commercial Banks.

The implication of the research results is that there is a tendency for Bank Indonesia (BI) policy regarding the capital adequacy ratio (CAR) in national banking, empirically presenting a ratio that does not differ significantly between conventional commercial banks and syari'ah commercial banks. Although these two types of banking have different characteristics. Shari'ah banking does not impose a fixed interest charge on customer funds deposited in the bank, because it is replaced by a profit-sharing concept compared to conventional banking, which apparently does not cause a significant difference in CAR with conventional banking. This is quite reasonable because BI uses the same standards that must be adhered to by the two types of banking, namely a minimum CAR of $8 \%$ so that each must refer to the CAR provisions set by the OJK.

\section{Comparison of Non Performing Loans / Financing between Conventional Commercial Banks and Islamic} Commercial Banks

The test results show that there are significant differences in non-performing loans / financing (NPL / NPF) between Conventional Commercial Banks and Islamic Commercial Banks, according to the researchers' expectations. The results are also consistent with the research Sapariyah et.al (2017), Wijayanti et.al (2017), Samad and Anan (2017), Setyabudi et.al (2017), Fahmi et.al (2018) which prove that there are significant differences in non-performing loans / financing between Conventional Commercial Banks with Islamic Commercial Banks.

Implications of The results of the study show that there is a level of management differences in the management of non-performing loans in banks, so that it greatly determines the quality of credit / financing that is distributed. Bank Indonesia regulations stipulate that the NPL / NPF is below 5\%. Sharia Commercial Banks have better credit management quality than Conventional Commercial Banks because of this many Islamic banks do not yet have a corporate segment so that the NPF risk is smaller. In addition, many Islamic banking financing has entered the non-productive or consumer sector, which has a lower risk character.

Comparison of Return On Asset Ratio between Conventional Commercial Banks and Islamic Commercial Banks

The test results show that there is a significant difference in return on assets (ROA) between Conventional Commercial Banks and Islamic Commercial Banks, according to the researchers' expectations. The results correspond to Ibrahim (2016), Samad and Anan (2017), Wijayanti (2017), Sapariyah et.al (2017), Hardianti and Saifi (2018) which prove that there is a significant difference in return on assets between Conventional Commercial Banks and Islamic Commercial Banks.

The results imply that there is a tendency for return on assets (ROA) of Islamic general banks to be worse than return on assets of syari'ah commercial banks. Why is that?, because Islamic banks are more focused on the function as an ordinary commercial bank, while the function as an investment bank is not maximized. This is understandable because there is indeed an inadequate competency side when engaged in investment financing. Meanwhile, conventional commercial banks, which are more likely to carry out their functions as investment banks, generate very high potential for profitability so that they greatly support their profitability performance.
Financial

Performance

Comparison

(Empiric Study on

Conventional

Commercial Banks and Sharia

Commercial Banks 2012-2018) 
Commercial Banks

The results showed that there were significant differences in operating expenses to operating revenue (BOPO) between Conventional Commercial Banks and Islamic Commercial Banks, according to the researchers' expectations. The results are also in accordance with Solikah et.al (2016), Wijayanti (2017), Wahyuni and Efriza (2017), Tabash (2017), Khan (2017) which proves that there is a significant difference between Operating Expenses to Operating Avanue for Conventional Commercial Banks and Banks. Sharia General. This difference shows that Conventional Commercial Banks are more optimal in managing operations in increasing revenue compared to Islamic Commercial Banks.

The results imply that there is a tendency that conventional commercial banks are better at maximizing their use of funds so that there is no idle and are better able to maintain credit quality so that the burden of CKPN for credit can be more controlled, compared to syari'ah commercial banks. In addition, conventional banks are also better able to reduce interest expenses by encouraging cheap savings funds, as well as making operational costs efficiency.

Comparison of Loan / Financing Deposit Ratio between Conventional Commercial Banks and Islamic Commercial Banks

The results showed that there was a significant difference in loan / financing to deposit ratio between Conventional Commercial Banks and Islamic Commercial Banks according to the expectations of the researchers. Resultin accordance with theSaputra (2016), Solikah (2017), Thayib et.al (2017), Sapariyah et.al (2017), Hardianti and Saifi (2018) who prove that there are significant differences in loan / financing deposit ratio conventional commercial banks and Islamic commercial banks. . This difference shows that Conventional Commercial Banks have a better level of liquidation.

These results imply that there is a tendency that conventional commercial banks, in the midst of a fairly rapid growth of third party funds (DPK), are more capable of channeling credit, especially for mortgage and commercial (construction) loans than syari'ah commercial banks. So even though there is a growing trend of new funds, but able to be balanced with lending has moved positively.

\section{CONCLUSION}

There is no significant difference in the Capital Adequency Ratio between Conventional Commercial Banks and Islamic Commercial Banks, indicating that the main difference between Islamic banking isapply a fixed interest charge on customer funds, as applied to conventional banking does not cause a significant difference in CAR. There is a significant difference in non-performing loan / financing (NPL / NPF) between Conventional Commercial Banks and Islamic Commercial Banks, indicating that Islamic Commercial Banks are better than conventional commercial banks in managing NPL / NPF, because they do not have or are still very limited in the general corporate segment. has a high level of risk.

The significant difference in return on assets (ROA) between Conventional Commercial Banks and Islamic Commercial Banks, indicates that conventional commercial banks are better at their profitability performance, because they tend to carry out more functions as investment banks that have the potential to generate very high profitability. Meanwhile, Shari'ah Commercial Banks are morefocuses on functioning as an ordinary commercial bank. The significant difference between operating expenses to operating revenue (BOPO) between Conventional Commercial Banks and Islamic Commercial Banks indicates that conventional commercial banks are better at utilizing funds maximally so that they are better able to maintain credit quality, compared to Syari'ah Commercial Banks. The significant difference between the loan / financing to deposit ratio between conventional commercial banks and syari'ah commercial banks indicates that conventional commercial banks are more capable of extending credit, especially for mortgage and commercial (construction) loans compared to syari'ah commercial banks.

\section{References}

Arinta, YN (2016). Comparative Analysis of Financial Performance between Islamic Banks and Conventional Banks (Case Study on Bank Syariah Mandiri and Bank Mandiri). Muqtasid: Journal of Islamic Economics and Banking, 7 (1), 119-140.

Budiartini, SN, Agung, AP, \& Gama, AW (2017). Comparative Analysis of the Performance of Islamic Commercial Banks and Conventional Commercial Banks in Indonesia. Journal of Management Forum, 15 (2).

Dodoev, K. (2018). Comparative Analysis of Islamic and Conventional 
Banks in CAMEL Model in Case of Malaysia. Global Journal of Management and Business Research.

Fahmi, JA, Diana, N., \& Afifudin. (2018). Comparative Analysis of the Financial Performance of Sharia Banks and Conventional Banks (Case Study at Bank Muamalat Syariah and Bank Negara Indonesia Period 20122015. E-JRA, 7 (10).

Hardianti, D., \& Saifi, M. (2018). Comparative Analysis of the Financial Performance of Conventional Commercial Banks and Sharia Commercial Banks Based on Bank Financial Ratios (Studies on Conventional Commercial Banks and Sharia Commercial Banks Registered and Supervised by the Financial Services Authority (OJK) for the 2013-2016 Period). Journal of Business Administration, 60 (2), 10-18.

Ibrahim, AJ (2015). Empirical Findings on the Profitability of Banks in Qatar: Islamic vs. Conventional. International Journal of Business and Commerce, 5 (4), 63-78.

Jahja, USA (2012). Comparative analysis of the financial performance of Islamic banking with conventional banking. Epistemé: Journal of the Development of Islamic Sciences, 7 (2), 337-360.

Khan, A. (2018). Financial performance analysis of public and private sector banks through camel model. asian $\mathrm{j}$. appl. sci. technol. (open.

Khan, I., Khan, M., \& Tahir, M. (2017). Performance comparison of Islamic and conventional banks: empirical evidence from Pakistan. International Journal of Islamic and Middle Eastern Finance and Management.

Rahayu, E., Isharijadi, I., \& Amah, N. (2017, October). Comparison between the Financial Performance of Conventional Commercial Banks and Islamic Commercial Banks Through Liquidity, Solvency and Profitability Approaches. In FIPA: Accounting Education Scientific Forum (Vol. 5, No. 1).

Ramadhan, KD (2016). Financial statement analysis in measuring company performance at PT. Ricky Kurniawan Kertapersada (Makin Group) Jambi. VALUTA, 2 (2), 190-207.

Rivai, V., Basyir, S., Sudarto, S., \& Veitzal, AP (2013). Commercial Bank Management from Theory to Practice. Depok: PT RajaGraffindo Persada.

Rosiana, D., \& Triaryati, N. (2016). Comparative Study of Financial Performance in Conventional Banks and Islamic Banks in Indonesia. Management E-Journal, 5 (2).

Samad, A., \& Anan, E. (2017). Comparison of Financial Performance between Conventional Commercial Banks and Islamic Commercial Banks in Indonesia. EBBANK, Vol 8 (1), 67-88.

Sapariyah, RA, Choerudin, A., Setyorini, Y., \& Khristiana, Y. (2017). Financial Performance of Conventional and Syariah Banks: An Empirical Studies in Indonesia. Journal of Islamic Banking and Finance, 5 (2), 9-14.

Saputra, SE (2016). Comparative Analysis of the Financial Performance of Conventional Banks and Islamic Banks. JOM FEKON, 3 (1).

Setyaningsih, A., \& Utami, SS (2013). Comparative Analysis of Islamic Banking Financial Performance with Conventional Banking. Journal of Economics and Entrepreneurship, 13 (1), 100-115.

Setyabudi, IK, Utami, SS, \& Wibowo, E. (2017). Comparative Analysis of Islamic Banking Financial Performance with Conventional Banking (Case Study at PT Bank Syariah Mandiri and PT Bank Mandiri (Persero) for the 2012-2016 Period. Journal of Economics and Entrepreneurship, 17 (4), 543-557.

Solikah, HM, Mardani, RM, \& Wahono, B. (2017). Comparative Analysis of the Financial Performance of Islamic Commercial Banks and Conventional Commercial Banks in Indonesia (Empirical Study on Banking Companies on the Indonesia Stock Exchange. Warta Ekonomi, 7 (17).

Suliyanto. 2011. Applied Economics: Theory and Application with SPSS 1st Edition Yogyakarta: ANDI Yogyakarta.

Suyono. (2017). Comparative Analysis of Financial Performance of Sharia Banks With Bank Registered in Indonesia Stock Exchange. Bilanca's Journal, 1 (2).

Suyono. (2017). Comparative Analysis of Financial Performance of Sharia Banks With Bank Registred in Indonesia Stock Exchange. BILANCIA, 1 (2).

Tabash, M., Yahya, A., \& Akhtar, A. (2017). Financial Performance Comparison of Islamic and conventional banks in the United Arab Emirates (UAE). ICABML Conference Proceedings, 20 (07).

Thayib, B., Murni, S., \& Maramis, J. (2017). Comparative Analysis of the Financial Performance of Islamic Banks and Conventional Banks. EMBA Journal, 5 (2), 1759-1768.

Wahyuni, M., \& Efriza, RE (2017). Comparative Analysis of the Financial Performance of Islamic Banks and Conventional Banks in Indonesia. International Juornal of Social Science and Business, 1 (2), 66-74.

Wijayanti, A., Nisari, LK, \& Titisari, KH (2017). Sharia Banks VS Conventional Banks: Financial Performance Based on Financial Ratios. Journal of Socio-Economic Dynamics, 6 (2). 
Other References:

Bank Indonesia (2011). Bank Indonesia Regulation No.13 / 24./DPNP dated 25 October 2011. (http://www.bi.go.id, accessed February 24, 2019).

Financial Fervices Authority. (2014). Indonesian Banking Statistics 2014. (http://www.ojk.go.id, accessed 18 December 2018)

Financial Fervices Authority. (2018). Indonesian Banking Statistics 2018. (http://www.ojk.go.id, accessed January 25, 2019)

Financial Fervices Authority. (2018). Banking Booklet 2018 edition 5. (http://www.ojk.go.id, accessed 8 February 2018) 